\title{
Impact of the Great Recession in the Social Welfare Indicators Related to the Labour Market in Andalusia *
}

\author{
Ricardo OCAÑA-Riola a , Piedad MARTín-Olmedo a , Gracia MARoto- \\ NAVARro a , MARÍA DEL MAR GARCÍA-CALVENTE a , JosÉ MARÍA MAYORAL- \\ CORTÉS $^{\text {b }}$, JOSEFA RUIZ-FERNÁNDEZ ${ }^{\text {b }}$, JOSÉ JUAN SÁNCHEZ-CRUZ ${ }^{\text {a }}$ \\ ${ }^{a}$ Escuela Andaluza de Salud Pública ${ }^{* *}$, Campus Universitario de Cartuja, Cuesta del Observatorio 4, \\ Apartado de Correos 2.070, 18011 Granada, España. E-mail: ricardo.ocana.easp@juntadeandalucia.es, \\ piedad.martin.easp@juntadeandalucia.es, gracia.maroto.easp@juntadeandalucia.es, mariadelmar.garcia.easp@juntadeandalucia.es, \\ josejuan.sanchez.easp@juntadeandalucia.es \\ ${ }^{b}$ Secretaría General de Salud Pública y Consumo, Consejería de Salud de la Junta de Andalucía, Edificio \\ Arena 1, Avenida de la Innovación, 41020 Sevilla, España. E-mail: josem.mayoral@juntadeandalucia.es, \\ josefarniz@juntadeandalucia.es
}

\begin{abstract}
Unemployment, economic deprivation and poverty are social welfare indicators. All form a cycle of chained factors which begins with the loss of employ. The objectives of this study were to describe the trend of unemployment, economic deprivation, poverty and self-employment in men and women in Andalusia during the period 2000-2013, as well as evaluating possible significant changes in trend after the beginning of the Great Recession. The results showed a significant worsening of the indicators of unemployment, economic deprivation and risk of poverty in Andalusia since 2008. On the other hand, an improvement of self-employment was observed in both sexes.
\end{abstract}

Keywords: Great Recession, Social Welfare Indicators, Self-Employment, Trend Analysis.

\section{Impacto de la Gran Recesión en los indicadores de bienestar social relacionados con el mercado de trabajo}

\section{RESUMEN}

El desempleo, la privación económica y la pobreza son indicadores de bienestar social. Todos forman un ciclo de factores encadenados que comienza con la pérdida del empleo. Los objetivos de este estudio fueron describir la evolución del desempleo, la privación económica, la pobreza y el autoempleo en hombres y mujeres en Andalucía durante el período 2000-2013, así como evaluar cambios en la tendencia tras el inicio de la Gran Recesión. Los resultados muestran un empeoramiento significativo de los indicadores de desempleo, privación económica y riesgo de pobreza en Andalucía desde 2008 y una mejora del autoempleo en ambos sexos.

Palabras clave: Gran recesión, Indicadores de bienestar social, Autoempleo, Análisis de tendencias

JEL Classification: E0, E2

\footnotetext{
* This paper shows some of the results of the research project "Evolution of the Millennium Development Goals in Andalusia in the context of global economic crisis", which was developed at the Andalusian School of Public Health. The study was funded by the Ministry of Health and Social Welfare of Andalusia (grant number PI-0473-2013). Seplin-Statistical Solutions contributed to analyze part of the data. The indicators analyzed in this study can be viewed at www.demap.es/es/ productos/odma.

** Todos los autores de la Escuela Andaluza de Salud Pública están vinculados al Instituto de Investigación Biosanitaria de Granada.
}

Artículo recibido en octubre de 2016 y aceptado en noviembre de 2016

Artículo disponible en versión electrónica en la página www.revista-eea.net, ref. ə-35104 


\section{INTRODUCTION}

The twentieth century brought great changes in the political, economic and social context of most countries in the world. Among them is the globalization process, which was generated in the Occident and was promoted worldwide during the last decades of the past century (Hamilton, 2009). In 2000, the Secretary-General of the United Nations (UN), Kofi Annan, promulgated the benefits of globalization in terms of growth, increased living standards and new opportunities. However, he warned about the existence of negative reactions among citizens because these benefits were very unequally distributed, and because the global market was not based on shared social objectives. Disparities in the distribution of wealth, the poverty of millions of people, the frequency of conflicts, the unemployment and the precarious work are factors that contribute to an unsustainable development model. Such model will not succeed unless countries take corrective actions through world agreement (Annan, 2000). For this purpose, main countries of the world established as common objective achieving full employment and decent work for all people in 2015 (The General Assembly, 2000; World Bank, 2013). In the same way, the European Union (EU) proposed, within the Europe 2020 strategy, to reach a share of $75 \%$ employment in the European population between 20 and 64 years (European Commission, 2010). However, the events that have occurred during the first decade of the 21st century are not promoting achieving these goals. The crisis of the American subprime mortgages in 2007, the economic and financial crisis of 2008, and the Eurozone crisis of 2010 have triggered a serious economic, political and social problem at international level which remains today (Marichal, 2013).

Since 2008, the economic growth has shown a significant slowdown in most countries of the world, and the unemployment rate continues its upward trend in many of them. In 2014, 201 million people were unemployed and 61 million had lost their jobs since the start of the economic crisis (ILO, 2015). Although the employment situation is improving in some advanced economies, especially in Japan and USA, the recovery remains difficult in much of Europe and the situation worsens in some emerging or developing countries. The countries that are achieving to reduce unemployment have experienced a substantial deterioration in the quality of employment and they have increased the precarious job. It is expected that in 2020 global unemployment shall rise by 8 million people and $7 \%$ of workers shall live in extreme poverty (ILO, 2015). Also, the economic crisis does not affect men and women equally, due to social inequality between sexes, stereotypes and different gender roles implemented in all sectors of society. The study of the past economic crises from a gender perspective has revealed that, after the crisis, male employment always recovers before that female employment, female employment becomes more precarious, and the 
progress in gender equity are contracted. All these factors contribute to increase inequality between men and women (Galvez \& Rodriguez, 2011).

Unemployment, economic slowdown and social inequality are deteriorating the economical, political and social stability of many advanced countries, encouraging the emergence of new social protest movements (Tilly \& Wood, 2012). In some advanced economies, income inequality has increased significantly during the crisis, approaching the situations experienced in emerging economies. In addition, the risk of poverty or social exclusion is increasingly present in the leading World Powers, mainly in the southern European countries (ILO, 2015; Tilly \& Wood, 2012). Recent researches explain the increase of poverty in these countries through a cycle of enchained factors that begins with unemployment. Thus, the rise in job loss increases economic deprivation of people. In turn, the sustained economic deprivation is a precursor of poverty and social exclusion of citizens. As a result, unemployment, economic deprivation and poverty are linked factors which condition social development, welfare and health of countries and regions (O'Campo et al., 2015). Most countries worldwide promote self-employment as a part of the solution to this situation. However, the gender gap in entrepreneurship is a serious problem today that needs specific policies to achieve optimal results (Obschonka et al., 2014).

In a context of Great Recession like the current, continuous monitoring of indicators related to social conditions derived from the labour market (unemployment, economic deprivation and poverty), as well as indicators linked to the self-employment, has special relevance to establish appropriate policies that allow achieving an appropriate social development in all countries and regions worldwide. In particular, the targets of the Europe 2020 strategy can be affected by the relentless rise in unemployment, increasing poverty and deteriorating living conditions of world citizenship.

Andalusia is one of the 17 Autonomous Communities that make up Spain. With a surface area of $87,597 \mathrm{~km}^{2}$ and a population of 8,388,875, it accounts for $17 \%$ of the Spanish territory and 18\% of the Spanish population (INE, 2015a). According to these figures, Andalusia is the most populated and second largest autonomous region in Spain, so it is comparable in extension and population to many European countries. Currently, it is the region with the highest unemployment in Spain and Europe, it is one of the regions of lower per capita income, and it shows, along with Extremadura, the lowest Human Development Index of the country (Herrero et al., 2010; INE, 2015a). These circumstances make Andalusia to be particularly vulnerable to recessions and economic crises. For this reason, the surveillance and monitoring of social welfare indicators related to the labour market are essential tasks in so critical situations like the current. 
The objectives of this study were to describe the trend of unemployment, economic deprivation, poverty and self-employment in men and women in Andalusia during the period 2000-2013, as well as evaluating possible significant changes in trend after 2008, the year of the beginning of the economic crisis in Spain.

\section{METHOD}

\subsection{Design}

An ecological study was devised using the year as the unit for analysis.

\subsection{Scope}

The study was conducted in Andalusia as a whole using annual data from the period 2000-2013.

\subsection{Variables}

Four indicators disaggregated by sex were used: Unemployment, economic deprivation, poverty or social exclusion and self-employment (Table 1).

Table 1

Social welfare indicators related to the labour market

\begin{tabular}{|c|c|c|c|}
\hline Indicator & Description & Period & $\begin{array}{c}\text { Source of } \\
\text { information }^{1}\end{array}$ \\
\hline Unemployment & $\begin{array}{l}\text { Number of unemployed persons per } 100 \text { active } \\
\text { persons }\end{array}$ & $2000-2013$ & Labour Force Survey \\
\hline Economic deprivation & $\begin{array}{l}\text { Number of people who reported having much } \\
\text { difficulty making ends meet, per } 100 \text { inhabitants }\end{array}$ & 2004-2012 & $\begin{array}{l}\text { Living Conditions } \\
\text { Survey }\end{array}$ \\
\hline $\begin{array}{l}\text { Poverty or social } \\
\text { exclusion }\end{array}$ & $\begin{array}{l}\text { Number of people at risk of poverty or social } \\
\text { exclusion, after social transfers, per } 100 \\
\text { inhabitants }\end{array}$ & 2004-2012 & $\begin{array}{l}\text { Living Conditions } \\
\text { Survey }\end{array}$ \\
\hline Self-employment & $\begin{array}{l}\text { Number of people working on their own, or in a } \\
\text { family business, per } 100 \text { employed persons }\end{array}$ & $2000-2013$ & Labour Force Survey \\
\hline
\end{tabular}

Source: Information come from the National Institute of Statistics (INE).

Unemployment: Number of unemployed persons per 100 active persons. The indicator was obtained disaggregated by age groups to study unemployment among young (16-24 years), young adults (25-29 years), adults (30-54 years) and adults close to retirement (55-65 years).

Economic deprivation: Number of people who reported having much difficulty making ends meet, per 100 inhabitants. The information was unavailable by age groups.

Poverty or social exclusion: Number of people at risk of poverty or social exclusion, after social transfers, per 100 inhabitants. According to the criteria 
established by Eurostat, a person is at risk of poverty or social exclusion if he/she lives with low incomes (has a income equivalent lower than $60 \%$ of the median equivalent income or per unit of consumption), suffers severe material deprivation (lives in a home that lacks at least four essential concepts of a total of nine) or shows low intensity of employment (lives in a household where members of working-age worked less than $20 \%$ of their total potential for work during the previous year). This indicator is known as AROPE and it is used in Europe 2020 (Eurostat, 2013; INE, 2013). The indicator was obtained disaggregated by age groups to study child poverty (15 or younger), poverty in working-age population (16-64 years) and poverty in retirement age (65 and over).

Self-employment: Number of people working on their own, or in a family business, per 100 employed persons. The information was unavailable by age groups.

\subsection{Sources of information}

Information on poverty or social exclusion and economic deprivation was obtained from the Living Conditions Survey (INE, 2013). The indicators on unemployment and self-employment were extracted from the Labour Force Survey (INE, 2008). Both surveys are conducted annually by the National Institute of Statistics (Table 1).

\subsection{Statistical analysis}

Time series graphs were used to describe the temporal trend of the indicators through the study period. Additionally, an online surveillance system was developed for monitoring purposes using Tableau Desktop software. Such surveillance system is available at www.demap.es/es/productos/odma.

A segmented regression model was used for each indicator to assess statistically significant trend changes. In this model, time is divided in $k$ break points, which are represented by $t_{i}, i=1, \cdots, k$. Thus, the model can be expressed in the form:

$$
\ln (E[Y \mid t])=\beta_{0}+\beta_{1} t+\sum_{i=1}^{k} \delta_{i} f_{i}(t)
$$

where $Y$ is the indicator, $t$ is the year, $\beta_{0}$ is the intercept, $\beta_{1}$ and $\delta_{i}$ are successive slopes, and $f_{i}(t)$ is a time function whit values $f_{i}(t)=0$ for $t \leq t_{i}$ and $f_{i}(t)=\left(t-t_{i}\right)$ for $t>t_{i}, i=1, \cdots, k$. Model parameters were estimated by Weighted Least Squares method. The optimal number of break points was obtained using permutation tests (Kim et al., 2000). Once the model was 
estimated, the Annual Percentage of Change (APC) was calculated for each interval defined by the break points (Clegg, 2009). Jointpoint and SPSS software were used to carry out statistical data analysis.

\section{RESULTS}

\subsection{Unemployment}

In 2000 , the unemployment rate was $16.7 \%$ in male and $32.5 \%$ in female. During the period 2000-2013 several statistically significant trend changes were observed.

Figure 1

Trend of unemployment in Andalusia by sex and age groups, 2000-2013

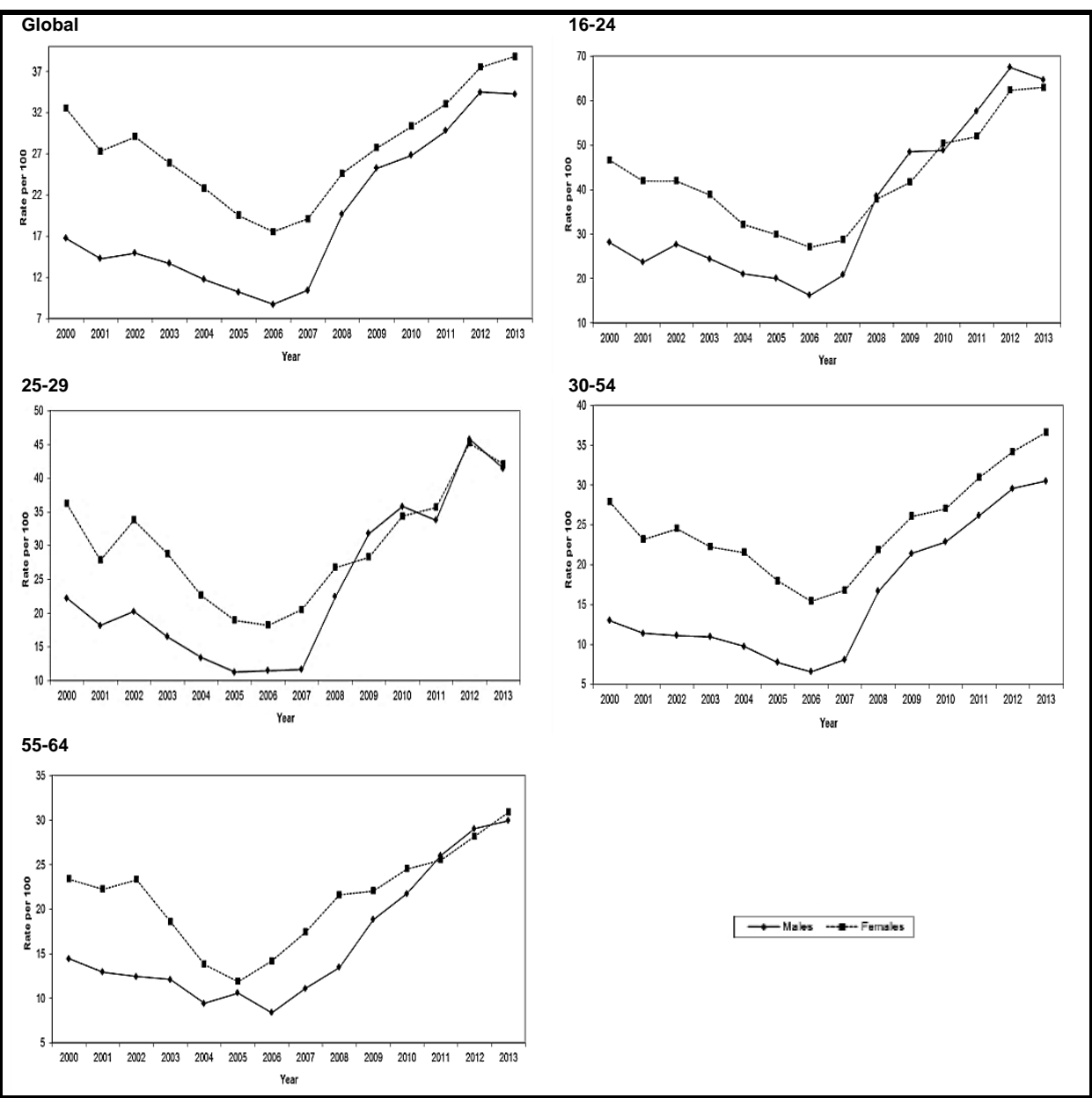

Source: Own elaboration. 
Thus, between 2000 and 2006 there was a decline of male and female unemployment, with APC equal to $-10.3 \%$ and $-8.8 \%$ respectively (Table 2 ). Then, the rate increased between 2006 and 2013, with APC equal to 11.8\% in women. In men, the APC was 41.3\% during 2006-2009 and 8.6\% in the period 2009-2013 (Table 2). The behaviour of the trend was similar in all the age groups.

\section{Table 2}

Annual Percentage of Change of the social welfare indicators related to the labour market in Andalusia, 2000-2013

\begin{tabular}{|c|c|c|c|c|c|c|c|c|c|c|}
\hline \multirow{2}{*}{$\begin{array}{l}\text { MALES } \\
\text { Indicator }\end{array}$} & \multirow[b]{2}{*}{ Age } & \multicolumn{3}{|c|}{ Trend 1} & \multicolumn{3}{|c|}{ Trend 2} & \multicolumn{3}{|c|}{ Trend 3} \\
\hline & & Period & $\operatorname{APC}^{(1)}$ & Cl $95 \%{ }^{(2)}$ & Period & $\operatorname{APC}^{(1)}$ & $\mathrm{Cl} 95 \%{ }^{(2)}$ & Period & $\mathrm{APC}^{(1)}$ & $\mathrm{Cl} 95 \%{ }^{(2)}$ \\
\hline \multirow{5}{*}{ Unemployment } & Global & $2000-2006$ & $-10.3^{\wedge}$ & $(-13.9,-6.5)$ & 2006-2009 & $41.3^{\wedge}$ & $(12.5,77.5)$ & $2009-2013$ & $8.6^{\wedge}$ & $(3.4,14)$ \\
\hline & $16-24$ & 2000-2006 & $-8.0^{\wedge}$ & $(-12.8,-2.9)$ & 2006-2009 & $40.3^{\wedge}$ & $(3.4,90.5)$ & $2009-2013$ & $8.7^{\wedge}$ & $(0.4,17.7)$ \\
\hline & $25-29$ & 2000-2006 & $-12.4^{\wedge}$ & $(-19,-5.3)$ & $2006-2009$ & 45.20 & $(-8.3,129.7)$ & $2009-2013$ & 8.60 & $(-1.7,20.1)$ \\
\hline & $30-54$ & $2000-2006$ & $-10.4^{\wedge}$ & $(-14,-6.6)$ & 2006-2009 & $45.5^{\wedge}$ & $(16.7,81.4)$ & $2009-2013$ & $9.5^{\wedge}$ & $(4.8,14.3)$ \\
\hline & $55-65$ & 2000-2006 & $-7.5^{\wedge}$ & $(-11.4,-3.4)$ & 2006-2011 & $24.5^{\wedge}$ & $(16.6,32.9)$ & 2011-2013 & 5.80 & $(-7.9,21.5)$ \\
\hline Economic deprivation & Global & 2004-2012 & $4.5^{\wedge}$ & $(0.4,9.6)$ & - & - & - & - & - & - \\
\hline \multirow{4}{*}{ Poverty or social exclusion } & Global & 2004-2012 & $3.1^{\wedge}$ & $(1.1,5.1)$ & - & - & - & - & - & - \\
\hline & 15 or less & 2004-2012 & 1.9 & $(-1.0,5.0)$ & - & - & - & - & - & - \\
\hline & $16-64$ & 2004-2012 & $5.4^{\wedge}$ & $(2.9,7.9)$ & - & - & - & - & - & - \\
\hline & 65 or more & 2004-2012 & $-6.5^{\wedge}$ & $(-9.6,-3.4)$ & - & - & 一 & - & - & 一 \\
\hline Self-employment & Global & $2000-2002$ & $-8.4^{\wedge}$ & $(-16.0,0.0)$ & $2002-2010$ & -0.40 & $(-1.5,0.8)$ & $2010-2013$ & $6.3^{\wedge}$ & $(1.6,11.3)$ \\
\hline \multicolumn{2}{|l|}{ FEMALES } & \multicolumn{3}{|c|}{ Trend 1} & \multicolumn{3}{|c|}{ Trend 2} & \multicolumn{3}{|c|}{ Trend 3} \\
\hline Indicator & Age & Period & $\operatorname{APC}^{(1)}$ & $\mathrm{Cl} 95 \%^{(2)}$ & Period & $\mathrm{APC}^{(1)}$ & Cl $95 \%{ }^{(2)}$ & Period & $\operatorname{APC}^{(1)}$ & $\mathrm{Cl} 95 \%{ }^{(2)}$ \\
\hline \multirow{5}{*}{ Unemployment } & Global & $2000-2006$ & $-8.8^{\wedge}$ & $(-12.1,-5.4)$ & $2006-2013$ & $11.8^{\wedge}$ & $(9.2,14.5)$ & - & - & - \\
\hline & $16-24$ & $2000-2006$ & $-8.5^{\wedge}$ & $(-11.7,-5.1)$ & $2006-2013$ & $13.6^{\wedge}$ & $(10.5,16.7)$ & - & - & - \\
\hline & $25-29$ & $2000-2006$ & $-10.0^{\wedge}$ & $(-15.4,-4.2)$ & $2006-2013$ & $13.6^{\wedge}$ & $(8.8,18.7)$ & - & - & - \\
\hline & $30-54$ & $2000-2006$ & $-7.9^{\wedge}$ & $(-11.5,-4.1)$ & $2006-2013$ & $12.3^{\wedge}$ & $(9.6,15.1)$ & - & - & - \\
\hline & $55-65$ & $2000-2005$ & $-11.0^{\wedge}$ & $(-17.3,-4.3)$ & 2005-2013 & $10.6^{\wedge}$ & $(7.9,13.4)$ & 一 & 一 & - \\
\hline Economic deprivation & Global & 2004-2012 & $3.9^{\wedge}$ & $(0.6,7.4)$ & - & - & - & - & - & - \\
\hline \multirow{4}{*}{ Poverty or social exclusion } & Global & 2004-2012 & 0.9 & $(-0.9,2.6)$ & - & - & - & - & - & - \\
\hline & 15 or less & 2004-2012 & 1.2 & $(-1.9,4.5)$ & - & - & - & - & - & - \\
\hline & $16-64$ & 2004-2012 & $3.1^{\wedge}$ & $(1,5.3)$ & - & - & - & - & - & - \\
\hline & 65 or more & $2004-2012$ & $-7.3^{\wedge}$ & $(-9.4,-5.2)$ & - & - & - & - & - & - \\
\hline Self-employment & Global & $2000-2010$ & $-4.0^{\wedge}$ & $(-5.1,-2.9)$ & $2010-2013$ & 3.00 & $(-4.6,11.2)$ & - & - & - \\
\hline \multicolumn{11}{|c|}{${ }^{1}$ Annual Percentage of Change } \\
\hline \multicolumn{11}{|c|}{${ }^{2}$ Confidence Interval, with confidence level 1- $\alpha=0.95$} \\
\hline \multicolumn{11}{|c|}{ ^Annual Percentage of Change statistically significant, with significant level $\alpha=0.05$} \\
\hline Source: Own elabor & ation. & & & & & & & & & \\
\hline
\end{tabular}

\subsection{Economic deprivation}

In $2004,18 \%$ of men and $17.5 \%$ of women reported having great difficulty making ends meet. During the period 2004-2012 there was a statistically significant upward trend in both sexes (Figure 2), with APC equal to $4.5 \%$ in male and 3.9\% in female (Table 2). 
Figure 2

Trend of economic deprivation (2004-2012) and self-employment (2000-2013) in Andalusia by sex groups

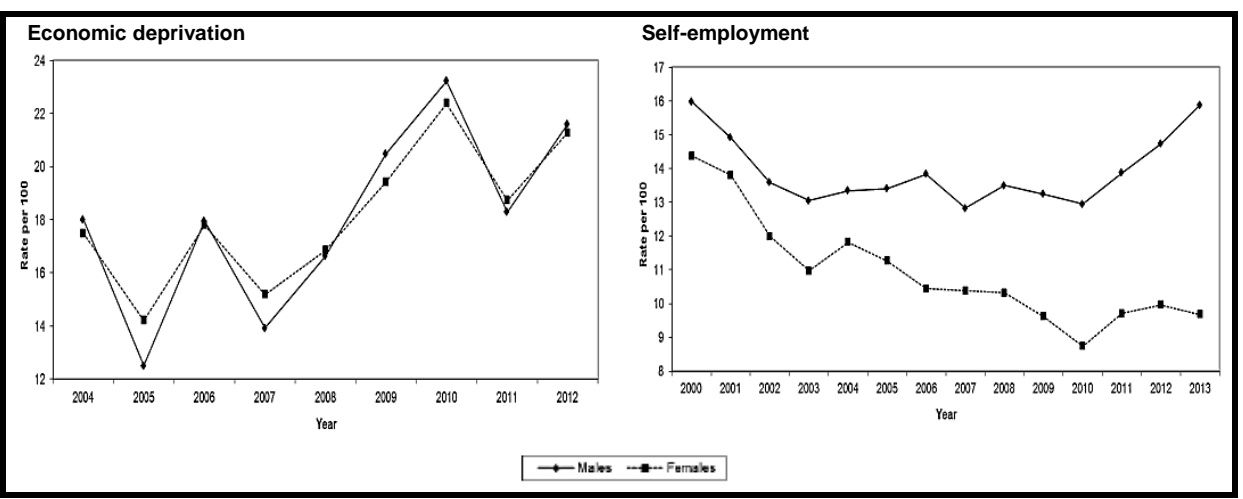

Source: Own elaboration.

\subsection{Poverty or social exclusion}

An increasing trend of the poverty risk rate was observed between 2004 and 2012 (Figure 3), with APC equal to 3.1\% in men and $0.9 \%$ in women (Table 2). In 2012, 39\% of men and 37\% of women were at risk of poverty in Andalusia. However, such overall trend was not replicated for each age group. A statistically significant trend was found only in the age groups older than 16 years (Table 2).

In 2004, 30.6\% of men and 34.1\% of women between 16 and 64 years old were at risk of poverty. A statistically significant increasing trend was observed during the period 2004-2012 (Figure 3), with APC equal to 5.4\% in men and $3.1 \%$ women (Table 2).

Figure 3

Trend of poverty or social exclusion in Andalusia by sex and age groups, 2004-2012

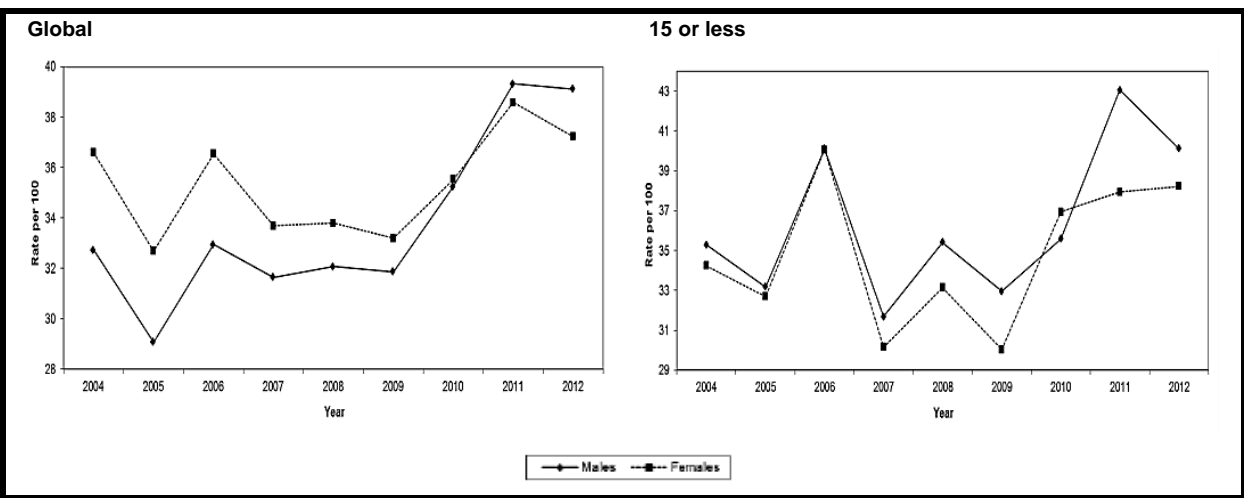


Figure 3 (continue)

Trend of poverty or social exclusion in Andalusia by sex and age groups, 2004-2012

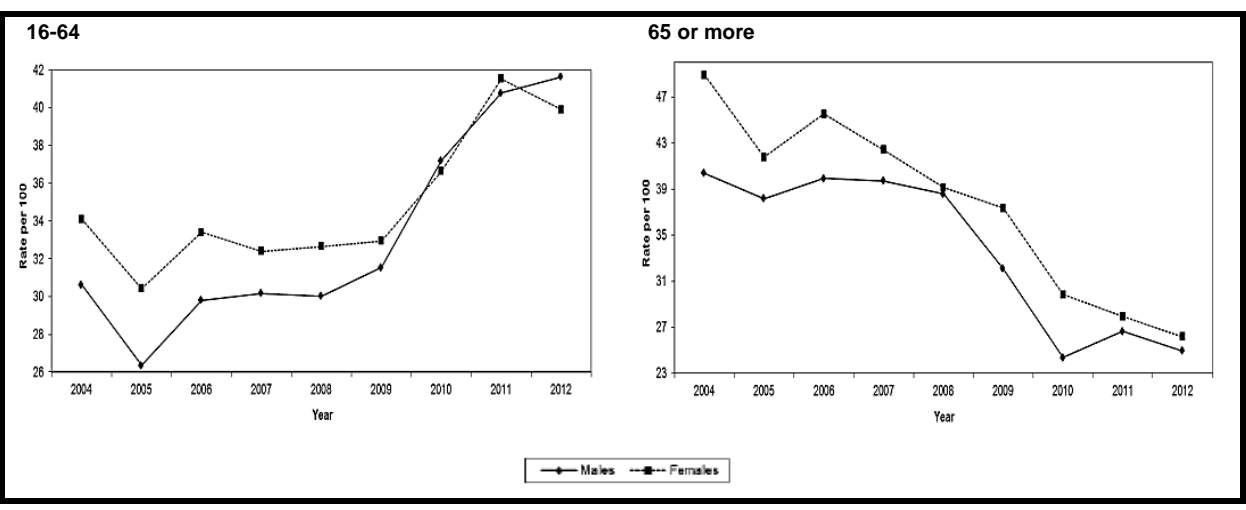

Source: Own elaboration.

The group of people aged 65 or older experienced a different situation. In $2004,40.4 \%$ of the male population and $48.9 \%$ of the female population was at risk of poverty. A statistically significant downward trend was observed during the period 2004-2012 (Figure 3), with APC equal to $-6.5 \%$ in men and $-7.3 \%$ in women (Table 2).

\subsection{Self-employment}

In $2000,16 \%$ of the employed men and $14.4 \%$ of the employed women was self-employed. Between 2000 and 2010 there was a decline in the percentage of male and female self-employment (Figure 2). In women, the APC was $-4 \%$ in the period 2000-2010. However, in men, the APC was -8.4\% during 2000-2002 and $-0.4 \%$ in 2002-2010, that latter without statistically significance (Table 2). Between 2010 and 2013, the percentage of self-employment grew in both sexes, with APC equal to $6.3 \%$ in male and $3 \%$ in female employed population. However, the increase was not statistically significant in women. This difference in the percentage of change caused a gradual increase in the gender gap that peaked in 2013 (Figure 2).

\section{DISCUSSION}

In this study, four indicators were analysed: Unemployment, economic deprivation, poverty or social exclusion and self-employment. Unemployment and self-employment are two of the indicators referred in the dominant reference framework to combat poverty and social exclusion in the world, setting the political decision-making in both developing and developed countries (United Nations, 2015). Economic deprivation, defined as the percentage of individuals who report having much difficulty in making ends meet, is a major subjective 
economic stressor used in Europe and Spain because it could be considered as a consequence of precarious job or unemployment, as well as a precursor of poverty or poor living conditions of citizens (Faura et al., 2012; Gudmundsdottir, 2013; Whelan \& Maître, 2013). Finally, the AROPE indicator is the poverty measurement used in the European countries under the Europe 2020 strategy. In the context of advanced societies, AROPE replaces the indicator "proportion of population below $1 \$$ purchasing power parity (PPP) a day", which was originally defined in the context of developing countries (United Nations, 2010; Oudesluys-Murphy, 2015). Both economic deprivation and risk of poverty or social exclusion are calculated from subjective measurements of the Survey of Living Conditions. These kinds of measurements could produce a response bias in respondents and, as a result, the results could be spurious. However, recent studies have proven the reliability of these measurements, especially those related to living conditions and welfare of the individual (Crettaz \& Suter, 2013; Ravallion, 2012).

\subsection{Unemployment}

Since 2008, the financial crisis has led to the closure of more than 400,000 Spanish companies. This situation has contributed to double the unemployment rate during the period 2008-2013 and to place Spain among the countries of the EU-28 with the highest unemployment, preceded only by Greece (Barchfield, 2014; Eurostat, 2014 Eurostat, 2015a).

The results of this study revealed an even more precarious situation in Andalusia. After years of decline, male and female unemployment began to grow significantly in this Autonomous Community in all age groups since 2006, precursor year of the economic crisis. Male unemployment, that in previous years had been much lower than female unemployment, increased rapidly until to reduce the gender gap and achieving similar figures to female unemployment, especially in younger people and older than 54 years. Studies in other countries have reported similar results, which can be explained by the strong impact of the crisis on construction and industry sectors, two traditionally male occupations (Baussola et al., 2015).

Although the behaviour of the unemployment trend was similar in Spain and the European Union (EU), the impact of the crisis has been different in each region. So, while in Andalusia male and female unemployment in young people between 16 and 24 years reached 65\% in 2013, these figures stood at around 55\% in Spain and did not exceed 23\% in the EU (Eurostat, 2015a). In part, the high youth unemployment in Spain and Andalusia can be explained by the increased of the early school leaving occurred between 2000 and 2008 with the aim to access to a labour market dominated by the property sector, which broke with the arrival of the economic crisis and it left jobless most of that population 
(Sabater, 2014). In 2000, 35.5\% of young people enrolled in Andalusian schools did not finish secondary education, rising to $38.5 \%$ in 2008. Since the beginning of 21th century, this early school leaving has traditionally been higher in men than in women, reaching the maximum difference in 2009 with $44.2 \%$ of men and 30.2\% in women (Directorate General of European Funds, 2013; Sabater, 2014). The risk of long-term unemployed of these young people is higher than the risk of young people who finish secondary education. Moreover, when they achieve to get jobs, the occupation uses to be low skilled, with less training requirements, low salary and related to construction or agriculture (Sabater, 2014). To palliate this situation, education for employment must be one of the key strategies of the EU. Some important objectives are to promote the completion of secondary education, to encourage the enrolment in post-secondary education, to achieve the construction of appropriate skills and to promote the training to get a suitable job (Mourshed et al., 2014).

Overall, Spain remains today the country with more unemployment in the EU, registering a rate of 23\% in the first quarter of 2015 (Eurostat, 2015b). In turn, Andalucía is the Spanish Autonomous Community with worst employment situation, reaching $33.6 \%$ of unemployment in the first quarter of 2015 (30.9\% of male unemployment and $36.9 \%$ of female unemployment) (INE, 2015b). This situation affects the welfare of citizens and can be related to worsening health. In this way, some studies have showed the relationship between unemployment and mental health, including depression, anxiety and psychosomatic symptoms, among others (Paul \& Moser, 2009; Zivin et al., 2011). Other researches have confirmed the relationship between jobless and worsening of health throughout life (Kondo, 2012; Kaplan, 2012; Calatano et al., 2011; Mustard et al., 2013.). Also, labour market instability, inequality and reduced social protection are factors related to mortality from specific causes, especially those related to mental health, circulatory system and respiratory system (Zivin et al., 2011; Mustard et al., 2013; Stuckler et al., 2009; Van den Berg et al., 2011).

\subsection{Economic deprivation}

The severe unemployment that Spain and Andalusia have suffered during the economic crisis has negatively impacted the lives of citizens. Between 2009 and 2012, the income of households decreased by 6\% in Spain and 5\% in Andalusia. This drop was sharper than those observed in other EU countries since the start of the economic crisis (Gómez \& López, 2014). Thus, taking into account consumer prices and purchasing power parity, the equivalent income of Spanish households in 2011 was 68\% lower than the income of French households, 71\% lower than the income of British households, and well below the countries of northern and central Europe (Economic and Social Council of Spain, 2013). This, 
coupled with the increasing private debt experienced by Spain in recent years (Izák, 2014; Schularick, 2014), explains the upward trend in the percentage of people who reported having much difficulty making ends meet that has been showed in this study. Currently, the economic deprivation rate in Andalusia is equal to $25.8 \%$, compared to $17.5 \%$ nationally. These figures place Andalucía between the Spanish Autonomous Communities with more severe economic deprivation (INE, 2015c).

\subsection{Poverty or social exclusion}

Unemployment, as well as economic deprivation derived from it, increases the chance of poverty and social exclusion of individuals (Vallcorba et al., 2009). In OECD countries, composed by the 34 most advanced countries worldwide, social inequality and poverty have increased dramatically since the beginning of the economic crisis in 2007-2008 (OECD, 2013). In 2013, the AROPE index showed that $24.5 \%$ of the population of the EU-28 was at risk of poverty or social exclusion and over a third of the population was in this situation in five Member States: Bulgaria (48 \%), Romania (40.4\%), Greece (35.7\%), Latvia (35.1\%) and Hungary (33.5\%) (Eurostat, 2015c). In Spain, this percentage was $27.3 \%$, having increased by 2.6 percentage points since 2009 . This means that during the period 2009-2013 the number of people at risk of poverty or social exclusion increased by $1,320,216$, reaching the absolute number of 12,866,431 persons in 2013 (Llano, 2015).

As in the EU and Spain, the results of this study showed a growing trend of the proportion of people at risk of poverty or social exclusion in Andalusia during the period 2004-2012, with some peculiarities in certain age groups. Thus, a significant increase in the percentage of men and women at risk of poverty or social exclusion was observed in the age group 16-64 years, coinciding with the population group that has fallen on unemployment. However, the percentage of people at risk of poverty or social exclusion decreased during the period 20042012 in the age group 65 and older, those most protected by social pension policies (Llano, 2015).

As in other countries, during the years preceding the economic crisis, the percentage of Andalusian women between 16 and 64 years at risk of poverty or social exclusion was higher than the percentage of men, due to gender inequalities in the access to the labour market, worst employment conditions and lower wages (Bennett \& Daly, 2014). However, the crisis has produced an important increase in male unemployment and, as a result, the gender gap was reduced in this age group. Similar results have been found in other EU countries (Barry, 2014).

Although the trend in Andalusia was similar to that observed in the whole of Spain for the same age groups, the percentage of poverty or social exclusion is much higher in this Autonomous Community. In 2013, Andalusia was the second 
region with the highest percentage of people at risk of poverty or social exclusion, reaching 38.3\% (Llano, 2015). In addition, an increase of 9 percentage points was observed since 2009, and the last official reports show that the percentage of people at risk of poverty or social exclusion had reached $42.3 \%$ in 2014. These figures confirm Andalusia as one of the Spanish Autonomous Communities with highest growth of the AROPE index since the beginning of the economic crisis, and, as a result, one of the regions more affected (INE, 2015c; Llano, 2015).

\subsection{Self-employment}

Recent researches have proven that most young Europeans at risk of poverty or social exclusion are students who combine their studies with low-skilled labour activities (Halleröd \& Ekbrand, 2015). The rise of unemployment, precarious employment, poverty and social inequality in the EU requires the coordination of the Member States to enhance job creation, whit special attention to young people. The European Employment Strategy is the main instrument of the EU policy to coordinate the employment policies of the countries, since its introduction in the Maastricht Treaty of 1992. Today, it is part of the Europe 2020 growth strategy and its implementation involves the application of specific measures for job creation, such as the promotion of self-employment and the support for social enterprises or new businesses (European Commission, 2012). During the period 2007-2013, the EU allocated $12.3 \%$ of total cohesion budget (42.292 million euro) for projects aimed at the implementation of preventive measures on the labour market, the generation of self-employment and the creation of new business, with particular attention to youth employment (Eurostat, 2014). In line with the European strategy, Spain implemented the Strategy for Entrepreneurship and Youth Employment 2013-2016, which led to the 11/2013 Law on measures to support entrepreneurship and to stimulate growth, with the aim of promoting self-employment (Fernandez \& Calvo, 2013). Since the beginning of the economic crisis, these measures have contributed to a gradual increase in the percentage of self-employment in Spain, ranking in 2014 among the five countries of the EU-28 with the highest rate of self-employment (Hatfield, 2015). The results of the present study showed that Andalusia has followed a similar trend. Since 2010, an increase in the percentage of selfemployed was observed in both sexes, with an annual percentage of change equal to $6.3 \%$ in the male working population and $3 \%$ in the female working population. This difference in the speed of change, as well as the highest percentage of self-employed that systematically was showed in men, have been found in other studies. The authors of such researches argue that part of the difference could be explained by social determinants of gender, personal characteristics, psychological factors, gender segregation of the occupations and unequal perception of risk to the business among sexes (Caliendo et al., 2011; Fossen, 2012; Saridakisa et al., 2014). 
The growth of self-employment in Andalusia could continue in the following years, after the implementation of specific measures post-2015 as the Action Plan for Self-Employment of Andalusia-Horizon 2020, the Incentive Program for Industrial Development and Creation of Employment in Andalusia and the Decree-Law 2/2015 on urgent measures to promote employability measures, the stability in employment, the return of the talent and the promotion of selfemployment in Andalusia. However, despite that the measures taken by the EU, Spain and Andalusia are generating self-employment and, as a result, they are mitigating the unemployment caused by the crisis, some authors point out the need to control the undesired increase of the false self-employment, that is, workers that are employed for a permanent service at the headquarters of a business and the employer requires them to pay their own social security contributions (Behling \& Harvey 2015; Williams, 2015). In addition, some studies suggest further promotion of education for employment and employability, as well as improving conditions for employment and selfemployment (Mourshed et al., 2014).

\section{CONCLUSIONS}

The Great Recession has led to a significant worsening of the indicators of unemployment, economic deprivation and risk of poverty or social exclusion in Andalusia. Today, this region is one of the Spanish Autonomous Communities in which the impact of the recession has been greater. The target of achieving full employment and the eradication of poverty by 2015, as proposed the United Nations, or achieving $75 \%$ of employment in the European population between 20 and 64 years and to reduce the number of people at risk poverty or social exclusion in 2020, as proposed in the Europe 2020 Strategy, is far from being achieved in Andalusia and Spain.

On the other hand, an improvement of self-employment was observed in both sexes since 2010 due to European, national and regional strategies. However, more specific policies are needed yet in Andalusia to reduce the gender gap in entrepreneurship.

In addition to the social and economic damage suffered since the beginning of the crisis, Andalusia left to be considered a priority geographic area of the European regional policy in 2014, which represents a major withdrawal of European structural funds for the period 2014-2020. Such situation could affect negatively on the recovery of the main economic and social indicators (Cardenete et al., 2014). In a strongly unfavourable context to the development, policies for social protection can contribute to the reduction of unemployment, economic deprivation and risk of poverty or social exclusion in Andalusia. Maintaining access to the basic social services and promoting the advancement of society are essential for this purpose (Gottret et al., 2009). The application of these social 
policies, together with the promotion of more specific employment strategies, will be important keys for the economic future of Andalusia.

In accordance with the Sustainable Development Goals post-2015, this study contributes to know the evolution of social inequalities within countries, allowing the future comparison with other regions of Spain, as well as providing information to reduce inequalities within and among countries (Hosseinpoor et al., 2015).

\section{BIBLIOGRAPHIC REFERENCES}

ANNAN, K.A. (2000). We the Peoples: The role of the United Nations in the 21st century (Millennium report of the Secretary-General, A/54/2000). New York: United Nations.

BARRY, U. (2014). "Gender perspective on the economic crisis: Ireland in an EU context". Gender, Sexuality \& Feminism, 1(2), pp. 82-103.

BAUSSOLA, M.; MUSSIDA, C.; JENKINS, J. and PENFOLD, M. (2015). "Determinants of the gender unemployment gap in Italy and the United Kingdom: A comparative investigation". International Labour Review, 154(4), pp. 537-562.

BEHLING, F. and HARVEY, M. (2015). "The evolution of false self-employment in the British construction industry: a neo-Polanyian account of labour market formation". Work, Employment \& Society, 29, 969-988.

BENNETT, F. and DALY, M. (2014). Poverty through a gender lens: Evidence and policy review on gender and poverty. Oxford: University of Oxford.

BRACHFIELD, P. (2014). Informe sobre la morosidad del crédito comercial en España. Madrid: EAE Business School.

CALIENDO, M.; FOSSEN, F.M. and KRITIKOS, A.S. (2011). Personality characteristics and the decision to become and stay self-employed: Discussion Paper No. 5566. Bonn: The Institute for the Study of Labour (IZA).

CARDENETE, M.A.; DELGADO, C. and LIMA, M.C. (2014). "The Structural Funds in Andalusia for the Programming Period 2014-2020: Time for Tightening Belts". European Planning Studies, 22(3), pp. 563-586.

CATALANO, R.; GOLDMAN-MELLOR, S.; SAXTON, K.; MARGERISON-ZILKO, C.; SUBBARAMAN, M.; LEWINN, K. and ANDERSON, E. (2011). "The health effects of economic decline". Annual Review of Public Health, 32, pp. 431-450.

CLEGG, L.X.; HANKEY, B.F.; TIWARI, R.; FEUER, E.J. and EDWARDS, B.K. (2009). "Estimating average annual percent change in trend analysis". Statistics in Medicine, 28, pp. 3670-3678.

CRETTAZ, E. and SUTER, C. (2013). "The impact of adaptive preferences on subjective indicators: An analysis of poverty indicators". Social Indicators Research, 114(1), 139152.

CONSEJO ECONÓMICO Y SOCIAL DE ESPAÑA (2013). Distribución de la renta en España: desigualdad, cambios estructurales y ciclos. Madrid: CES. 
DIRECCIÓN GENERAL DE FONDOS EUROPEOS (2013). El índice de desigualdad de género de Andalucía: Serie 2005-2012. Sevilla: Consejería de Innovación, Ciencia y Empleo de la Junta de Andalucía.

EUROPEAN COMMISION (2010). Europe 2020: A strategy for smart, sustainable and inclusive growth. Brussels: European Commission.

EUROPEAN COMMISSION (2012). Towards a job-rich recovery. Strasbourg: European Commission.

EUROSTAT (2013). The measurement of poverty and social inclusion in the EU: achievements and further improvements. Geneva: United Nations.

EUROSTAT (2014). Eurostat regional yearbook 2014. Luxemburg: Eurostat.

EUROSTAT (2015a). Europe in figures 2014-Eurostat yearbook. Luxemburg: Eurostat.

EUROSTAT (2015b). Eurostatistics: Data for short-term economic analysis. Luxemburg: Eurostat.

EUROSTAT (2015c). People at risk of poverty or social exclusion. Luxemburg: Eurostat. http://ec.europa.eu/eurostat/statistics-explained/index.php/People_at_risk_of_poverty _or_social_exclusion. [Last accsess: September 2016]

FAURA, U.; LAFUENTE, M. and LOSA, A. (2012). "Medición y análisis de la vulnerabilidad a la exclusión social en España (2004-2009)". Estudios de Economía Aplicada, 30(2), pp. 753(30 pag).

FERNÁNDEZ, M.F. and CALVO, F.J. (2013). La estrategia de emprendimiento y empleo joven en la Ley 11/2013: Desempleo, empleo y ocupación juvenil. Albacete: Bomarzo.

FOSSEN, F.M. (2012). "Gender differences in entrepreneurial choice and risk aversion: A decomposition based on a microeconometric model". Applied Economics, 44(14), 1795-1812.

GÁlVEZ, L. and RODRíGUEZ, P. (2011). "La desigualdad de género en las crisis económicas". Investigaciones Feministas, 2, 113-132.

GÓMEZ, M. and LÓPEZ, M.T. (2014). "Análisis del comportamiento de los ingresos de las familias españolas durante la crisis económica". Anuario Jurídico y Económico Escurialense, 47, 407-426.

GOTTRET, P.; GUPTA, V.; SPARKES, S.; TANDON, A.; MORAN, V. and BERMAN, P. (2009). "Protecting pro-poor health services during financial crises: lessons from experience". Advances in Health Economics and Health Services Research, 21, 23-53.

GUDMUNDSDOTTIR, D.G. (2013). "The Impact of Economic Crisis on Happiness". Social Indicators Research, 110, 1083-1101.

HALLERÖD, B. and EKBRAND, H. (2015). "Labour Market Trajectories and Young Europeans' Capabilities to Avoid Poverty, Social Exclusion and Dependency: A Comparative Analysis of 23 European Countries". Facing Trajectories from School to Work, 20, 141-158.

HAMILTON, S.M. (2009). Globalization. Minnesota: Abdo.

HATFIELD, I. (2015). Self-employment in Europe. London: Institute for Public Policy Research.

HERRERO, C.; SOLER, A. and VILLAR, A. (2010). Desarrollo humano en España 19802007. Valencia: Ivie.

HOSSEINPOOR, A.R.; BERGEN, N. and MAGAR, V. (2015). "Monitoring inequality: An emerging priority for health post-2015". Bulletin of the World Health Organization, 93, 591-591A. 
ILO (2015). World Employment and Social Outlook: Trends 2015. Geneva: International Labour Office.

INE (2008). Encuesta de Población Activa: Metodología. Madrid: INE.

INE (2013). Encuesta de Condiciones de Vida: Metodología. Madrid: INE.

INE (2015a). Spain in figures 2015. Madrid: INE.

INE (2015b). Encuesta de Población Activa - Primer Trimestre de 2015. Madrid: INE.

INE (2015c). Encuesta de Condiciones de Vida 2014. Madrid: INE.

IZÁK, V. (2014). "Private and Public Debt". European Financial and Accounting Journal, 9(1), 4-21.

KAPLAN, G. (2012). "Economic crises: Some thoughts on why, when and where they (might) matter for health. A tale of three countries". Social Science \& Medicine, 74, 643646.

KIM, H.J.; FAY, M.P.; FEUER, E.J. and MIDTHUNE, D.N. (2000). "Permutation Tests for Joinpoint Regression with Applications to Cancer Rates". Statistics in Medicine, 19, 335-351.

KONDO, N. (2012). "Socioeconomic disparities and health: Impacts and pathways". Journal of Epidemiology, 22, 2-6.

LLANO, J.C. (2015). El estado de la pobreza: Seguimiento del indicador de riesgo de pobreza y exclusión social en España 2009-2013. Madrid: European Anti Poverty Network (EAPN).

MARICHAL, C. (2013). Nueva historia de las grandes crisis financieras. Barcelona: Debate.

MOURSHED M.; PATEL J. and SUDER K. (2014). Education to employment: Getting Europe's youth into work. Washington, DC: McKinsey \& Company.

MUSTARD, C.A.; BIELECKY A.; ETCHES, J.; WILKINS, R.; TJEPKEMA, M.; AMICK, B.C. et al. (2013). "Mortality following unemployment in Canada, 1991-2001". BMC Public Health, 13, 441.

OBSCHONKA, M.; SCHMITT-RODERMUND, E. and TERRACCIANO, A. (2014). "Personality and the gender gap in self-employment: a multi-nation study". PLoS One, 9(8), e103805.

O'CAMPO, P.; MOLNAR, A.; NG, E.; RENAHY, E., MITCHELL, C., SHANKARDASS, K. et al. (2015). "Social welfare matters: A realist review of when, how, and why unemployment insurance impacts poverty and health". Social Science \& Medicine, 132, 88-94.

OCDE (2013). Growing risk of inequality and poverty as crisis hits the poor hardest. París: OCDE. http://www.oecd.org/newsroom. [Last access September 2016].

OUDESLUYS-MURPHY, A.M. (2015). "Millennium Development Goals in Europe". Archives of Disease in Childhood, 100, S72-S73.

PAUL, K. and MOSER, K. (2009). "Unemployment impairs mental health: Metaanalyses". Journal of Vocational Behavior, 74, 264-282.

RAVALLION, M. (2012). Poor, or just feeling poor? On using subjective data in measuring poverty. World Bank Policy Research Working Paper No. 5968. http://ssrn.com/abstract=2004930 [Last access September 2016].

SABATER, S. (ed). (2014). El abandono educativo temprano: Análisis del caso español. Valencia: IVIE. 
SARIDAKISA, G.; MARLOWB, S. and STOREYC, D.J. (2014). "Do different factors explain male and female self-employment rates?". Journal of Business Venturing, 29(3), 345362.

SCHULARICK, M. (2014). "Public and Private Debt: The Historical Record (1870-2010)". German Economic Review, 15(1), 191-207.

STUCKLER, D.; BAUS, S.; SUHRCKE, M. and MCKEE M. (2009). "The health implications of financial crisis: A review". Ulster Medical Journal, 78, 142-145.

THE GENERAL ASSEMBLY (2000). United Nations Millennium Declaration (A/RES/55/2). New York: United Nations.

TILLY, C. and WOOD, L.J. (2012). Social Movements 1768-2012. Colorado: Paradigm Publishers.

UNITED NATIONS (2010). The MDGs in Europe and Central Asia: Achievements, Challenges and the Way Forward. New York: United Nations.

UNITED NATIONS (2015). The Millennium Development Goals Report 2015. New York: United Nations.

VALLCORBA, M.; GARCÍA, C. and TOHARIA, L. (2009). Guía Metodológica: Definición, uso e interpretación de los indicadores de los Planes Nacionales de Acción para la Inclusión Social. Madrid: Ministerio de Sanidad y Política Social.

VAN DEN BERG, G.J.; DOBLHAMMER-REITER, G. and CHRISTENSEN, K. (2011). "Being born under adverse economic conditions leads to a higher cardiovascular mortality rate later in life: Evidence base on individuals born at different stages of the business cycle". Demography, 48, 507-530.

WHELAN, C. and MAÎTRE, B. (2013). "Material Deprivation, Economic Stress, and Reference Groups in Europe: An Analysis of EU-SILC 2009". European Sociological Review, 29(6), 1162-1174.

WILLIAMNS, C.C. (2015). "Tackling informal employment in developing and transition economies: A critical evaluation of the neo-liberal approach". International Journal of Business and Globalisation, 14(3), 251-270.

WORLD BANK (2013). World Development Indicators 2013. Washington, DC: World Bank.

ZIVIN, K.; PACZKOWSKI, M. and GALEA, S. (2011). "Economic downturns and population mental health: research findings, gaps, challenges and priorities". Psychological Medicine, 41, 1343-1348. 